\title{
APPLICATION OF THE RANDOM AMPLIFIED POLYMORPHIC DNA USING THE POLYMERASE CHAIN REACTION FOR EFFICIENT ELIMINATION OF DUPLICATE STRAINS IN MICROBIAL SCREENING
}

\section{FUNGI}

\author{
FUMIHIRO FUIIMORI and TORU OKUDA* \\ Department of Microbiology and Taxonomy, \\ Nippon Roche Research Center, \\ 200 Kajiwara, Kamakura, Kanagawa 247, Japan
}

(Received for publication September 27, 1993)

\begin{abstract}
For efficient fungal strain selection in microbial screening, we applied the random amplified polymorphic DNA (RAPD) method using the polymerase chain reaction (PCR). In order to evaluate this system, the genus Trichoderma was employed, because its species are difficult to distinguish from each other. We selected an appropriate oligonucleotide decamer, R28 (5'-ATGGATCCGC), determined the optimal cycles of PCR as 30 cycles, simplified the template preparation method, and determined optimal concentrations of the template and Taq DNA polymerase. We then examined 74 closely related strains of Trichoderma. The electrophoretic band patterns of the PCR products were compared. According to the statistical analysis with the phylogenetic analysis using parsimony (PAUP), the results were consistent with the morphological, physiological and ecological data on these strains. Therefore, we conclude that RAPD is a simple, efficient and reliable method for the selection of fungal strains employed in screening.
\end{abstract}

Microorganisms have traditionally been isolated and selected empirically by taxonomists in microbial screening. Such screening, however, is somewhat restricted because of repetitive encounters with possible duplicate strains. In addition, when similar strains are passed through a certain assay system based on their activity, it is difficult to say whether any one of them should be eliminated, because it takes time to examine these strains precisely. In a sense, the efficiency of a screening program depends on the skill of the taxonomist involved in eliminating such strains; the success of microbial screening does not always depend on the number of samples, but on their diversity. To improve this elimination process, we have applied the random amplified polymorphic DNA (RAPD) method using the polymerase chain reaction $(\mathrm{PCR})^{1,2)}$. The RAPD is now widely used for pure taxonomic works and geographical distribution studies of plant pathogens ${ }^{1,3,4)}$. This method provides characteristically short DNA products. The polymorphisms enable one to distinguish a minor difference between closely related genotypes with high sensitivity. The method is very rapid compared to restriction fragment length polymorphisms (RFLP) ${ }^{5,6)}$. We selected the genus Trichoderma in evaluating this method, because its species are difficult to distinguish from each other. In this report, we describe the establishment of a standard method of RAPD for fungi. The RAPD data are compared with the morphological, physiological, and ecological data of the strains examined. We also report briefly on the possible computerization of the data processing. Our final goal is to establish a routine method of image data analysis of the RAPD electrophoretic bands.

\section{Materials and Methods}

Strains

Trichoderma strains examined were listed in Table 1. Most strains were isolated in our laboratory 
Table 1. Strains examined.

\begin{tabular}{|c|c|c|c|}
\hline Species & No $/$ Strain/Source/Locality/Collection year & Species & No $/$ Strain/Source/Locality/Collection year \\
\hline \multicolumn{2}{|c|}{ Trichoderma harzianum 1} & 37 & NR 6954, Soil, Gumma Japan, 1988 \\
\hline $1^{\mathrm{a}}$ & NR 6891, Twig, Aichi Japan, 1988 & 38 & NR 6944, Pinus densiflora, Ibaraki Japan, 1988 \\
\hline \multirow[t]{2}{*}{2} & NR 6964, Xylaria polymorpha, München & \multirow{3}{*}{$\begin{array}{l}39 \\
40\end{array}$} & NR 6943, Pinus densiflora, Ibaraki Japan, 1988 \\
\hline & Germany, 1988 & & NR 6963 , basidiomycete fruiting body, Ibaraki \\
\hline 3 & NR 6920 , Rotten wood, Gumma Japan, 1988 & & Japan, 1988 \\
\hline 4 & NR 6945, Leaf litter, München Germany, 1988 & \multirow[t]{2}{*}{41} & NR 6926, Amanita pantherina, Ibaraki Japan, \\
\hline 5 & NR 5544, Soil, Kanagawa Japan, 1977 & & 1988 \\
\hline 6 & NR 5502, Soil, Kumamoto Japan, 1972 & 42 & NR 6918, Soil, India, 1988 \\
\hline \multirow[t]{2}{*}{7} & \multirow{2}{*}{$\begin{array}{l}\text { NR } 6884 \text {, basidiomycete fruiting body, Nagano } \\
\text { Japan, } 1987\end{array}$} & 43 & NR 6958, Sasa sp., Kanagawa Japan, 1988 \\
\hline & & 44 & NR 6936, Soil, Kanagawa Japan, 1988 \\
\hline \multicolumn{2}{|c|}{ Trichoderma aureoviride } & 45 & NR 6967, Leaf litter, Okinawa Japan, 1988 \\
\hline 8 & NR 6935, Soil, Nassau Bahama, 1988 & 46 & NR 6895, Pinus sp., Shizuoka Japan, 1988 \\
\hline 9 & NR 6931, Soil, Chiba Japan, 1988 & 47 & IMI 298371, (from IMI) Worthing United \\
\hline 10 & NR 6929, Soil, Chiba Japan, 1988 & & Kingdom \\
\hline 11 & IMI 112086, (from IMI) Egypt & 48 & ATCC 18647, (from ATCC) \\
\hline \multirow[t]{2}{*}{12} & NR 6897 , Leaf litter, Welwyn garden & \multicolumn{2}{|c|}{ Trichoderma inhamatum } \\
\hline & United Kingdom, 1988 & 49 & NR 6930, Soil, Chiba Japan, 1988 \\
\hline 13 & NR 6968, Soil, München Germany, 1988 & 50 & NR 6953, Soil, Gumma Japan, 1988 \\
\hline 14 & NR 6932, Soil, Greece, 1988 & 51 & NR 6915, Soil, Ibaraki Japan, 1987 \\
\hline 15 & IMI 293162, (from IMI), Gujurat India & 52 & NR 5531, Leaf litter, Kanagawa Japan, 1977 \\
\hline \multirow[t]{2}{*}{16} & \multirow{2}{*}{$\begin{array}{l}\text { IMI 304058, (from IMI), Beta vulgaris, } \\
\text { Pantnagar India }\end{array}$} & 53 & NR 7061, Soil, Kanagawa Japan, 1977 \\
\hline & & 54 & P 16561, Pinus sp., Okinawa \\
\hline 17 & IMI 299898, (from IMI), Ramwapur India & 55 & IMI 288110, (from IMI) Phillipines \\
\hline 18 & NR 5546, Soil, Kanagawa Japan, 1977 & 56 & IMI 300082, (from IMI), Gunnaruwa Sri Lanka \\
\hline 19 & NR 6883, Soil, Kanagawa Japan, 1987 & 57 & NR 5548, Soil, Tokyo Japan, 1977 \\
\hline 20 & P 16560, Pinus sp., Okinawa Japan & 58 & IMI 292106, (from IMI), Trinidad India \\
\hline 21 & NR 6940, Soil, Okinawa Japan, 1988 & \multicolumn{2}{|c|}{ Trichoderma viride } \\
\hline 22 & NR 6950, Soil, Okinawa Japan, 1988 & 59 & NR 5510, Soil, Bratislava Czechoslovakia, 1975 \\
\hline 23 & NR 6938, Soil, Okinawa Japan, 1988 & 60 & NR 6898 , Twig, Welwyn garden city United \\
\hline 24 & NR 6933, Soil, Geneva Switzerland, 1988 & & Kingdom, 1988 \\
\hline 25 & NR 5555, Soil, Tokyo Japan, 1977 & 61 & NR 6896, Leaf litter, Welwyn garden city \\
\hline 26 & NR 6934, Soil, United Kingdom, 1988 & & United Kingdom, 1988 \\
\hline 27 & ATCC 18651, (from ATCC) & 62 & NR 6955, Soil, Finland, 1988 \\
\hline \multicolumn{2}{|c|}{ Trichoderma harzianum 2} & 63 & NR 6969, Soil, München Germany, 1988 \\
\hline 28 & NR 6892, Leaf litter, Aichi Japan, 1988 & 64 & IMI 293250, (from IMI), Vellayami India \\
\hline 29 & NR 6894, Leaf litter, Aichi Japan, 1988 & 65 & IMI 295977, (from IMI), W. Bengal Kalyani \\
\hline \multirow[t]{2}{*}{30} & \multirow{2}{*}{$\begin{array}{l}\text { NR } 6890, \text { Wood with toadstool, Aichi Japan, } \\
1988\end{array}$} & & India \\
\hline & & 66 & NR 5566, Soil, Kumamoto Japan, 1977 \\
\hline 31 & NR 6893, Leaf litter, Aichi Japan, 1988 & 67 & IMI 304531, (from IMI), Selangor Malaysia \\
\hline 32 & NR 6887, Aphilophorales, Aichi Japan, 1988 & 68 & NR 5541, Leaf litter, Nagano Japan, 1978 \\
\hline \multirow[t]{2}{*}{33} & NR 6924 , basidiomycete fruiting body, Gumma & 69 & NR 6937, Soil, Okinawa Japan, 1988 \\
\hline & Japan, 1988 & \multirow[t]{2}{*}{70} & IMI 298375, (from IMI), Worthing United \\
\hline 34 & NR 6921, Rotten wood, Gumma Japan, 1988 & & Kingdom \\
\hline \multirow[t]{2}{*}{35} & \multirow{2}{*}{$\begin{array}{l}\text { NR } 6923 \text {, Polyporellus brumali, Gumma Japan, } \\
1988\end{array}$} & 71 & CBS 433.34, (from CBS) \\
\hline & & 72 & FP 5566, Pinus radiata \\
\hline \multirow[t]{2}{*}{36} & NR 6925 , basidiomycete fruiting body, Gumma & 73 & FP 5563, Pinus sylvestris \\
\hline & Japan, 1988 & 74 & FP 5564, Pinus radiata \\
\hline
\end{tabular}

a These numbers indicate the lane numbers in Fig. 6 .

during the past 20 years. Some reference strains were purchased from American Type Culture Collection, Rockville, U.S.A., (ATCC); Centraalbureau voor Schimmelcultures, Baarn, the Netherlands, (CBS); and the International Mycological Institute, Egham, Surrey, UK., (IMI). Strains with an initial (P or FP) were kindly supplied by Dr. TokUMASU of the University of Tsukuba, Tsukuba, Japan.

Morphology

The strains were examined mainly according to RIFAI ${ }^{7}$, however, we also referred to VeERKAMPs \& 
GAMS $^{8)}$, and BISSETT ${ }^{9 \sim 12)}$. They were cultured on oatmeal agar or $2 \%$ malt extract agar.

\section{Production of Metabolites}

The production of isonitrile antibiotics was examined according to OKUDA et al. ${ }^{13)}$. The production of brown pigments and yellow needle-like crystals was also recorded using the cultures grown on malt extract agar slants.

\section{Total Nucleotide Preparation of Trichoderma}

In order to simplify the template preparation, several methods of purification were compared. Liquid media, PYG and SYN were used. PYG consisted of $2 \%$ Polypepton, $1 \%$ yeast extract, and $2 \%$ glucose, while SYN consisted of $8 \%$ glucose, $0.2 \% \mathrm{NH}_{4} \mathrm{NO}_{3}, 1 \% \mathrm{KH}_{2} \mathrm{PO}_{4}, 0.025 \% \mathrm{MgSO}_{4} \cdot 7 \mathrm{H}_{2} \mathrm{O}, 0.002 \%$ $\mathrm{FeCl}_{3} \cdot 6 \mathrm{H}_{2} \mathrm{O}$, and $0.0014 \% \mathrm{MnSO}_{4}$. A loop of conidia was inoculated into $500-\mathrm{ml}$ Erlenmeyer flasks containing $100 \mathrm{ml}$ of these media and incubated on a rotary shaker at $27^{\circ} \mathrm{C}$ at $220 \mathrm{rpm}$ for 3 days. An agar slant culture (10 20 days old) on a modified malt extract agar was also tested. The template preparation methods compared were 1) a crude supernatant of a liquid culture; 2) mycelia treated with chitinase and proteinase $\mathrm{K}$; 3) a washing supernatant of agar culture; and 4) mycelia of an agar culture crushed between slide glass. For the treatment with enzymes above (No. 2), two hundred mg wet mycelia grown in PYG medium for 3 days were used as a source of template DNA. The mycelia were suspended in $350 \mu \mathrm{l}$ TE buffer ( $10 \mathrm{~mm}$ Tris- $\mathrm{HCl} \mathrm{pH} 8.0,1 \mathrm{~mm}$ EDTA) containing $0.5 \mathrm{mg}$ chitinase and $300 \sim 400 \mathrm{mg}$ glass beads $\left(4 \sim 5 \mathrm{~mm}\right.$ in diam.). The suspension was agitated for 1 minute and incubated at $37^{\circ} \mathrm{C}$ for 1 hour. A $100 \mu \mathrm{l}$ proteinase $\mathrm{K}$ solution $(1 \mathrm{mg} / \mathrm{ml})$ was added to the suspension and heated at $55^{\circ} \mathrm{C}$ for 1 hour. As a control, a purified DNA sample was obtained using a standard method described by OMORI et $a l .{ }^{14)}$. These preparations were treated with phenol-chloroform followed by precipitation with ethanol. The pellet (DNA template source) was dissolved in TE buffer and the concentration of templates was determined by measuring the absorption at $260 \mathrm{~nm}$.

Primers

Oligodeoxynucleotide primers were synthesized on a DNA/RNA synthesizer (Applied Biosystems, Model 392). Three primers used in this experiment were R2, 5'-AGTACAGGTC; R4, 5'-TCCTACGCAC; R28, 5'-ATGGATCCGC described by GoodwIN et al. ${ }^{1}$.

\section{RAPD Amplification}

The RAPD reaction was done in a total volume of $50 \mu 1$ containing 0.5 to 8 unit Taq DNA polymerase, $2.5 \mu \mathrm{M}$ of a single oligonucleotide decamer, $200 \mu \mathrm{M}$ each dNTP, $2.0 \mathrm{mM} \mathrm{MgCl}_{2}, 1 \times$ buffer provided by Pro Bio or Cetus, template DNA solution. The PCR was conducted at $92^{\circ} \mathrm{C}$ for 1 minute 25 to 45 cycles of denaturation at $92^{\circ} \mathrm{C}$ for 45 seconds, annealing at $34^{\circ} \mathrm{C}$ for 60 seconds, extension at $72^{\circ} \mathrm{C}$ for 90 seconds; then the final extension at $72^{\circ} \mathrm{C}$ for 10 minutes in a thermoreactor (Atto, Zymoreactor II). Ten $\mu$ l of the PCR product together with $500 \mathrm{ng}$ of the origin and front markers were electrophoresed at $50 \mathrm{~V}$ for 2 hours in Mupid 2 (Advance) on a $5 \times 10 \mathrm{~cm} 5 \%$ polyacrylamide gel ${ }^{15)}$. The electrophoretic bands were detected by staining with ethidium bromide. $p H Y$ was used as a standard marker for molecular weight. $\lambda$ DNA for the origin marker and $90 \mathrm{bp}$ DNA for the front marker were used to precisely determine Rf values. Various PCR cycles were also evaluated. Although Goodwin et al. ${ }^{1{ }^{1}}$ applied PCR at 45 cycles, we tested 25 to 45 cycles in order to select optimal conditions. Taq DNA polymerase from Cetus was compared with that from Pro Bio and the effect of their concentration of the reaction $(0.5$ to 8 units per $50 \mu$ I PCR solution) was examined.

\section{Image Analysis}

The electrophoretic band patterns were photographed, and image acquisition made using an image analyzer, Bio Image (Millipore). The Rf value of each band was automatically determined by the analyzer calculating the bands of $\lambda \mathrm{DNA}$ and $90 \mathrm{bp} \mathrm{DNA}$ as $\mathrm{Rf}$ values 0.00 and 1.00 . The Rf values of individual polymorphic DNAs were treated as variable characters. When a DNA band was observed at a certain variable character, the value 1 was given; at the vacant position, the value 0 was given. The raw data of $\mathrm{Rf}$ values was then converted to a data matrix of 0-1 (Table 2). We compared $\mathrm{Rf}$ values from different 
Table 2. Example of a primary data matrix for RAPD analysis.

\begin{tabular}{|c|c|c|c|c|c|c|c|c|c|c|c|c|c|c|c|c|c|c|c|c|c|}
\hline Strain & Variable $1 \ldots 10$ & 11 & 12 & 13 & 14 & 15 & 16 & 17 & 18 & 19 & 20 & 21 & 22 & 23 & 24 & 25 & 26 & 27 & 28 & 29 & $30 \ldots 99$ \\
\hline \multicolumn{22}{|c|}{ Trichoderma harzianum 1} \\
\hline NR 6891 & 1 & 1 & 0 & 0 & 1 & 0 & 0 & 1 & 0 & 1 & 0 & 0 & 1 & 0 & 0 & 1 & 1 & 0 & 0 & 0 & 0 \\
\hline NR 6964 & 0 & 0 & 0 & 0 & 1 & 0 & 0 & 1 & 0 & 0 & 1 & 0 & 1 & 0 & 0 & 1 & 1 & 0 & 0 & 0 & 0 \\
\hline NR 6920 & 1 & 0 & 0 & 1 & 0 & 0 & 0 & 1 & 0 & 1 & 0 & 0 & I & 0 & 1 & 0 & 1 & 0 & 0 & 0 & 0 \\
\hline NR 6945 & 0 & 1 & 0 & 0 & 1 & 0 & 1 & 0 & 0 & 1 & 1 & 1 & 0 & 0 & 1 & 1 & 0 & 0 & 0 & 0 & 1 \\
\hline NR 5544 & 0 & 0 & 0 & 0 & 0 & 1 & 1 & 0 & 0 & 1 & 0 & 0 & 1 & 0 & 0 & 0 & 0 & 0 & 0 & 0 & 0 \\
\hline NR 5502 & 1 & 0 & 0 & 0 & 1 & 0 & 0 & 1 & 0 & 1 & 0 & 0 & 1 & 0 & 0 & 0 & 1 & 0 & 0 & 0 & 0 \\
\hline NR 6884 & 0 & 0 & 0 & 0 & 0 & 0 & 0 & 0 & 0 & 1 & 0 & 0 & 0 & 0 & 0 & 1 & 0 & 0 & 0 & 0 & 0 \\
\hline
\end{tabular}

Variables correspond to $100 \times \mathrm{Rf}$ value.

Table 3. Example of a new data matrix for RAPD analysis.

\begin{tabular}{|c|c|c|c|c|c|c|c|c|c|c|c|c|c|c|c|c|c|c|c|c|c|c|}
\hline Strain & $\begin{array}{c}\text { New } \\
\text { variable } 1\end{array}$ & ... 10 & 11 & 12 & 13 & 14 & 15 & 16 & 17 & 18 & 19 & 20 & 21 & 22 & 23 & 24 & 25 & 26 & 27 & 28 & 29 & $30 \ldots 99$ \\
\hline \multicolumn{23}{|c|}{ Trichoderma harzianum I } \\
\hline NR 6891 & & 1 & 1 & 1 & 1 & 1 & 1 & 1 & 1 & 1 & 1 & 1 & 1 & 1 & 1 & 1 & 1 & 1 & 1 & 0 & 0 & 1 \\
\hline NR 6964 & & 0 & 0 & 0 & 1 & 1 & 1 & 1 & 1 & 1 & 1 & 1 & 1 & 1 & 1 & 1 & 1 & 1 & 1 & 0 & 0 & 1 \\
\hline NR 6920 & & 1 & 1 & 1 & 1 & 0 & 1 & 1 & 1 & 1 & 1 & 1 & 1 & 1 & 1 & 1 & 1 & 1 & 1 & 0 & 0 & 1 \\
\hline NR 6945 & & 1 & 1 & 1 & 1 & 1 & 1 & 1 & 1 & 1 & 1 & 1 & 1 & 1 & 1 & 1 & 1 & 1 & 0 & 0 & 1 & 1 \\
\hline NR 5544 & & 0 & 0 & 0 & 0 & 1 & 1 & 1 & 1 & 1 & 1 & 1 & 1 & 1 & 1 & 0 & 0 & 0 & 0 & 0 & 0 & 0 \\
\hline NR 5502 & & 1 & 1 & 0 & 1 & 1 & 1 & 1 & 1 & 1 & I & 1 & 1 & 1 & 1 & 0 & 1 & 1 & 1 & 0 & 0 & 1 \\
\hline NR 6884 & & 0 & 0 & 0 & 0 & 0 & 0 & 0 & 0 & 1 & 1 & 1 & 0 & 0 & 0 & 1 & 1 & 1 & 0 & 0 & 0 & 1 \\
\hline
\end{tabular}

Variables correspond to $100 \times \mathrm{Rf}$ value.

gels, taking their deviations into consideration. A set of three adjacent variable characters was thus grouped in a new variable character. For example, the variable character from 1 to 3 was renamed 1 , character 2 to 4 became 2 , and character 3 to 5 became 3 . When the value 1 existed within this new column, a new value 1 was given. If not, 0 was given. A new data matrix with fuzziness was finally completed as shown in Table 3.

\section{Analysis Using PAUP}

The 0-1 matrix data obtained as above was entered in a computer (Apple, Macintosh IIci or LC II) for statistical analysis. The phylogeny analysis using parsimony, the PAUP vers. $3.0 \mathrm{~s}$ was used to construct dendrograms ${ }^{16)}$. The PAUP bootstrap with a heuristic search $(1,000$ times replication) was used in finding the most parsimonious trees.

\section{Results}

\section{Morphological Analysis of Trichoderma Strains}

Among the 74 strains of Trichoderma listed in Table 1, 10 strains were identified as $T$. inhamatum Veerkamp \& Gams, 28 as T. harzianum Rifai, 20 as T. aureoviride Rifai and 16 as T. viride Pers.: Gray. On the average, the conidia of $T$. viride were the largest, the second were those of $T$. aureoviride, and $T$. inhamatum has the smallest conidia. Some strains of $T$. harzianum formed larger conidia that were similar to $T$. viride. These strains had a similar branching pattern of conidiophores to that of $T$. viride, as well. However, since they formed smooth conidia, they were distinct from $T$. viride. Therefore, as we reported previously ${ }^{17)}$, the $T$. harzianum forming larger conidia were tentatively renamed $T$. harzianum 1 , whereas the other strains of $T$. harzianum were tentatively assigned as $T$. harzianum 2 (Table 4).

\section{Detection of Secondary Metabolites}

Among the 74 strains examined, 16 strains produced at least one component of the isonitrile antibiotics 
Table 4. Average size of conidia and phialides of Trichoderma spp.

\begin{tabular}{|c|c|c|c|c|}
\hline \multirow{2}{*}{ Species } & \multicolumn{2}{|c|}{ Conidia } & \multicolumn{2}{|c|}{ Phialides } \\
\hline & Size $(\mu \mathrm{m})$ & Length/width ratio & Size $(\mu \mathrm{m})$ & Length/width ratio \\
\hline T. inhamatum & $2.5 \sim 3.0 \times 2.0 \sim 2.5$ & $1.10 \sim 1.19$ & $4.5 \sim 6.0 \times 2.5 \sim 3.5$ & $1.37 \sim 2.01$ \\
\hline T. harzianum 1 & $3.5 \times 3.0 \sim 3.5$ & $1.07 \sim 1.20$ & $6.5 \sim 8.0 \times 2.5 \sim 3.5$ & $2.03 \sim 2.79$ \\
\hline T. harzianum 2 & $2.5 \sim 3.5 \times 2.0 \sim 3.0$ & $1.10 \sim 1.17$ & $5.0 \sim 7.5 \times 3.0 \sim 3.5$ & $1.70 \sim 2.33$ \\
\hline T. aureoviride & $3.0 \sim 3.5 \times 2.5 \sim 3.0$ & $1.13 \sim 1.29$ & $6.0 \sim 10.5 \times 2.5 \sim 4.0$ & $1.53 \sim 3.93$ \\
\hline T. viride & $3.5 \sim 4.5 \times 3.0 \sim 4.0$ & $1.05 \sim 1.27$ & $7.0 \sim 9.5 \times 2.5 \sim 4.0$ & $1.84 \sim 3.16$ \\
\hline
\end{tabular}

Fig. 1. Isonitrile antibiotics.

A, isonitrin $\mathrm{C}$ (trichoviridin); $\mathrm{B}$, isonitrin $\mathrm{D}$; $\mathrm{C}$, isonitrinic acid $\mathrm{E}$ (dermadine).

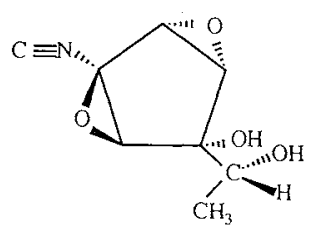

A

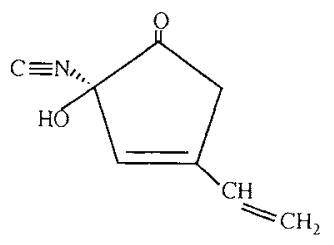

B

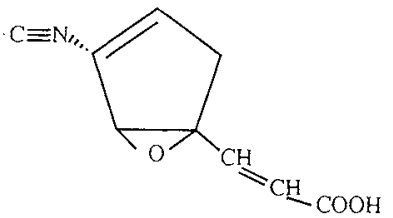

C
Fig. 2. Flow chart of the template DNA preparation for RAPD.

Culture grown in PYG medium

\section{Disruption mixture}

$\begin{array}{lr}\text { Wet mycelium } & 200 \mathrm{mg} \\ \text { Chitinase }(10 \mathrm{mg} / \mathrm{ml}) & 50 \mu 1 \\ \text { TE buffer (pH 8.0) } & 350 \mu 1 \\ \text { Glass beads } & 300 \sim 400 \mathrm{mg} \\ & \end{array}$

Incubation at $37^{\circ} \mathrm{C}$ for 1 hour

Addition of $100 \mu 1$ proteinase $\mathrm{K}$ soln $(1 \mathrm{mg} / \mathrm{ml})$, and incubation at $55^{\circ} \mathrm{C}$ for 1 hour

Treatment with phenol-chloroform

$$
\text { । }
$$

Addition of $1 / 10 \mathrm{vol}$. of $3 \mathrm{M} \mathrm{CH} \mathrm{CH}_{3} \mathrm{COONa}$ and $3 / 5 \mathrm{vol}$. of isopropanol, centrifugation at $15,000 \mathrm{rpm}$ for 10 minutes

Addition of TE buffer ( $\mathrm{pH} 8.0$ ), adjusted $\mathrm{A}_{260}$ to 3.0

Template DNA
Fig. 3. Effect of PCR cycles to electrophoretic bands.

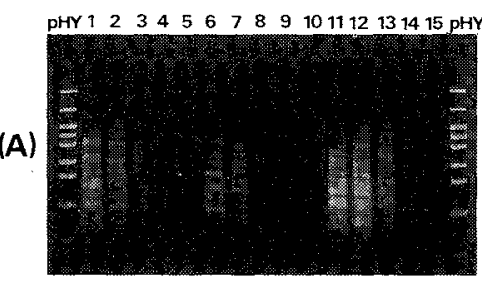

(B)

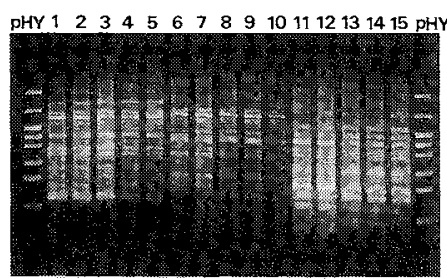

(A) Reaction without template DNA. (B) Reaction with template DNA. Lanes 1 to 5, primer R2; lanes 6 to 10 , primer R4; lanes 11 to 15 , primer R28. Lanes 1,6 and 11,45 cycles; lanes 2,7 and 12, 40 cycles; lanes 3,8 and 13,35 cycles; lanes 4,9 and 14,30 cycles; lanes 5,10 and 15,25 cycles. DNA used was purified from Trichoderma sp. 
(Fig. 1). The producers were restricted to T. harzianum 1 or $T$. viride ${ }^{13,17}$. On the other hand, the production of yellow crystals or dark red brown pigments was observed in cultures of T. inhamatum, T. harzianum 2, and T. aureoviride. There was no strain that produced both isonitrile antibiotics and these pigments.

\section{Establishment of a Standard Method for RAPD}

Although several methods have already been reported for RAPD analysis, ${ }^{1,2)}$ we had to determine a standard method in order to compare a large amount of data at one time. It was also essential to minimize the deviation between gels for computerization. Most methods of DNA template preparation could be used; however, treatment of wet mycelia grown in PYG medium plus glass beads with chitinase and proteinase $\mathrm{K}$ was found to be comparable to the purified DNA (Fig. 2). In addition, this method was less laborious permitting routine operation for a large number of samples. The DNA template solution was to be more than 0.1 at $\mathrm{A}_{260}$ for T. aureoviride, T. harzianum 1, and T. inhamatum, while it was to be more than 1.0 for $T$. harzianum 2 and $T$. viride, because a lower concentration of DNA from the latter two groups created a fewer bands in electrophoresis (data not shown). Therefore, we determined the optimal

Fig. 4. Dendrograms for T. viride using primers R2 (A), R4 (B) and R28 (C).

A

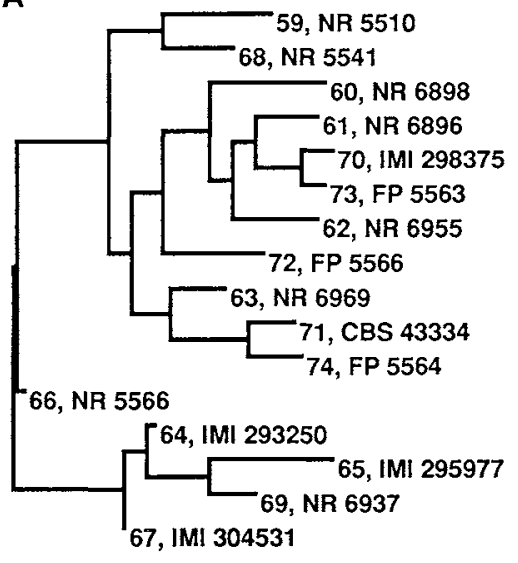

B

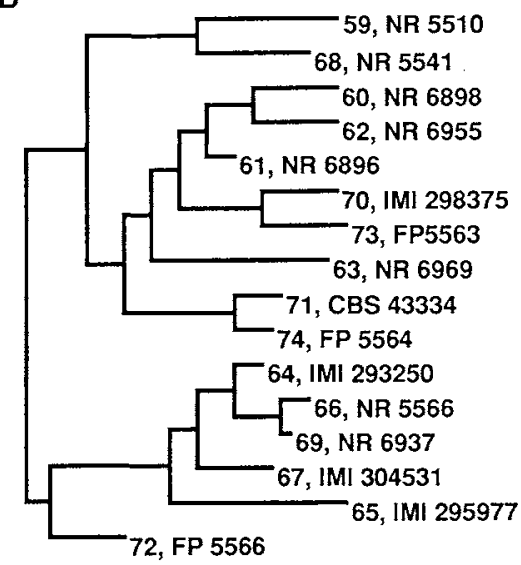

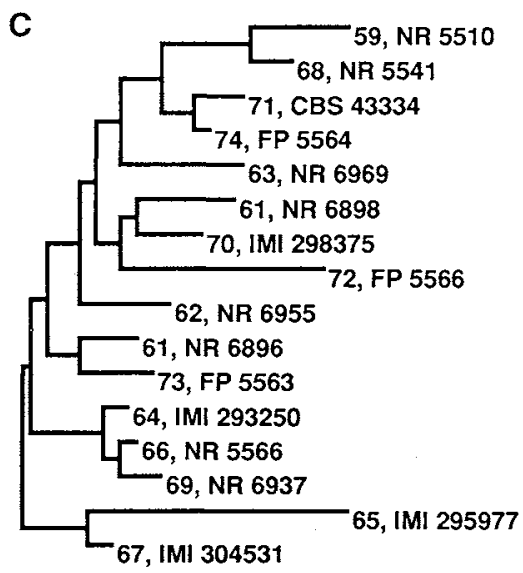

The number in front of the strain number indicates the number in the Table 1 and Fig. 6. 
concentration of the template as 1.0 at $\mathrm{A}_{260} \mathrm{~nm}$ so that almost uniform number of electrophoretic bands can be obtained. According to the evaluation of cycles for PCR, even without a template, PCR produced non specific products after more than 35 cycles of reactions (Fig. 3), thus we conducted reactions in less than 30 cycles. With any of the three primers, around 10 to 30 clear DNA bands appeared between one hundred base pairs and $2 \mathrm{Kbp}$. Around 10 to 30 bands were sufficient for the statistical analysis to obtain reliable and reproducible results within a short time. Fig. 4 shows dendrograms of 16 T. viride strains using 3 different primers, which demonstrated that all three trees were essentially identical. Primer R28 was the most suitable because it was able to amplify a larger number of DNA segments distributed in a certain wider range of DNA size. This made analysis easier and more accurate. The Taq DNA polymerase from either Cetus or Pro Bio could be used, but the latter produced a larger number of electrophoretic bands, probably due to its greater stability at high temperature. Finally, the standard procedure for RAPD was established as summarized in Fig. 5. By this

Fig. 5. Flow chart of the PCR for RAPD.

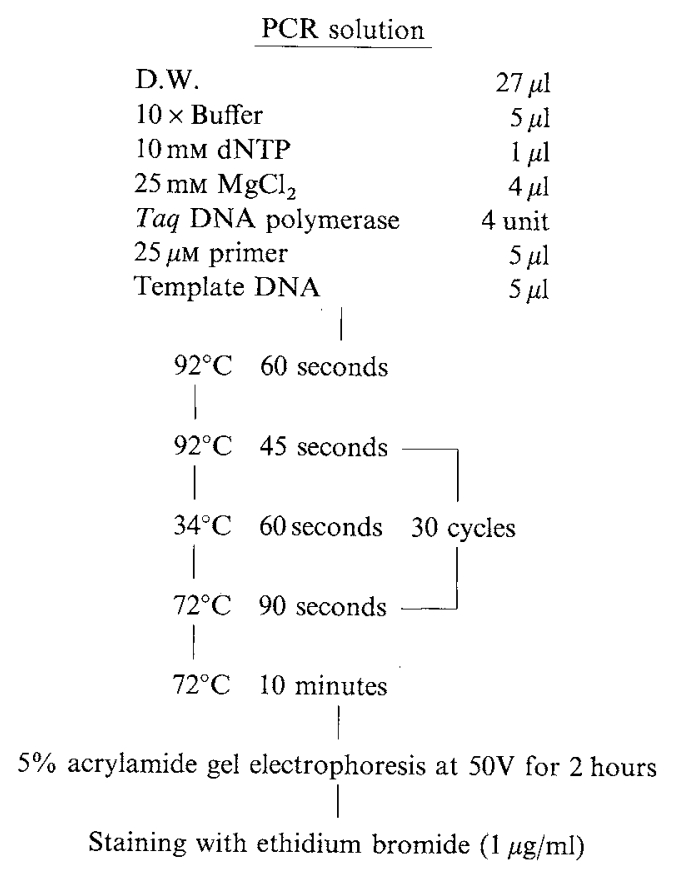

Fig. 6. RAPD electrophoretic results of the 74 strains of Trichoderma spp. by using primer R 28 .
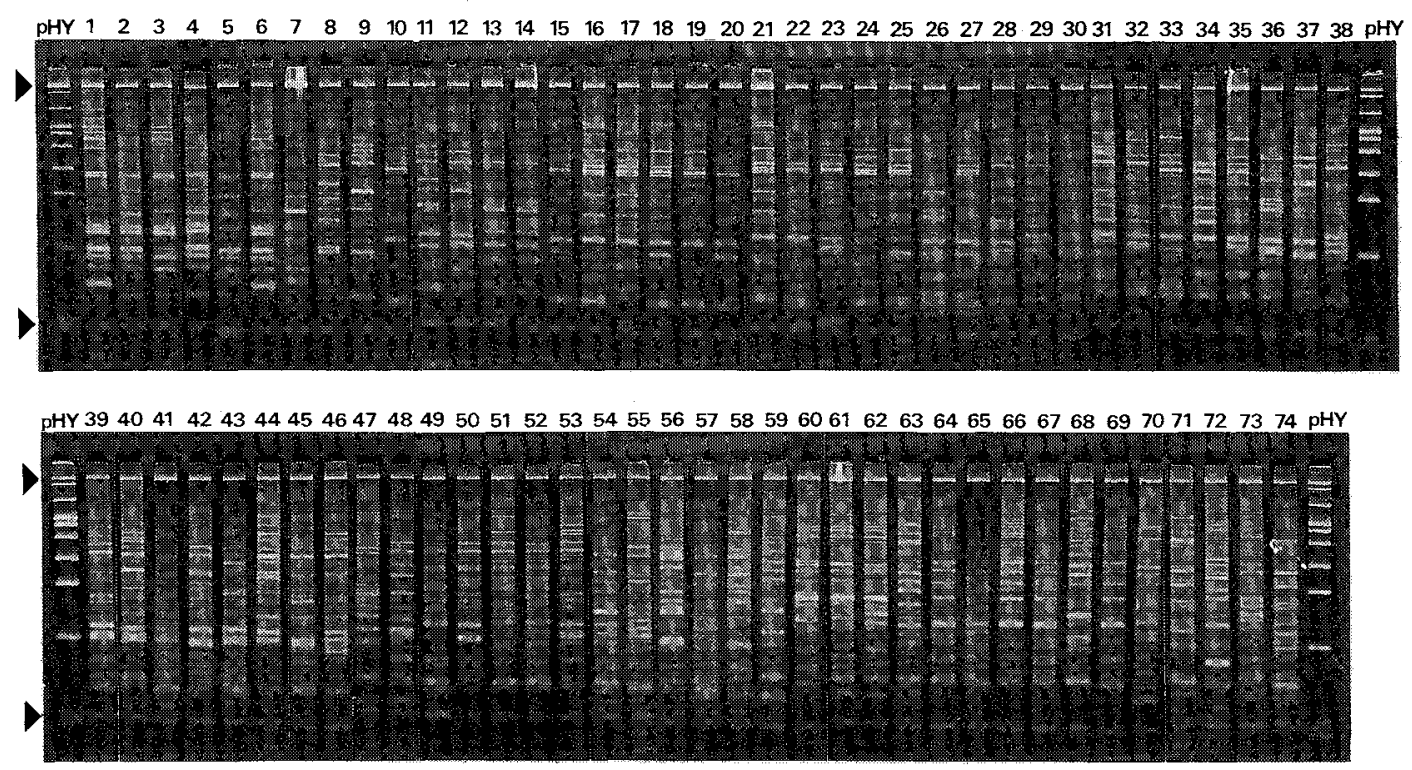

The lane number indicates the number in Table 1. pHY, pHY marker. Each lane contained $2 \mathrm{DNA}$ and $90 \mathrm{bp}$ DNA (arrowheads). 
standard method, we minimized the deviation of Rf values in the electrophoresis within 0.03 even between different gels. The RAPD of 74 Trichoderma strains using primer R28 is shown in Fig. 6.

\section{Discussion}

By minimizing the Rf value deviation between gels and converting the matrix described previously, we were able to process a large amount of data at one time.

Fig. 7 shows the dendrogram constructed by the PAUP based on the RAPD results in Fig. 6. All strains of $T$. harzianum 1 were clearly separated from T. harzianum 2 . The conidia of $T$. harzianum 1 were on average $3.5 \times 3.0 \sim 3.5 \mu \mathrm{m}$. The size of their conidia was larger than those of $T$. harzianum 2 , which were $2.5 \sim 3.5 \times 2.0 \sim 3.0 \mu \mathrm{m}$. The phialides of $T$. harzianum 1 were more slender (length/width ratio, $2.03 \sim 2.79$ ) than those of $T$. harzianum 2 (length/width ratio, 1.70 2.33). Furthermore, T. harzianum 1 characteristically produced some of isonitrile antibiotics (Fig. 1). No strains included in T. harzianum 2 produced these antibiotics, however some strains produced yellow needle-like crystals in malt extract agar slants or dark red brown soluble pigments in agar.

$T$. inhamatum is characterized by the formation of densely packed, short and almost globose phialides ${ }^{8)}$. However, there were several strains that had characteristics which were somewhere in between T. harzianum 2, $T$. inhamatum, and $T$. aureoviride. It was quite difficult to clearly distinguish these three species from each other ${ }^{11,12,17)}$ as well as clealy delineate the three by electrophoretic band analysis.

Interestingly, several strains isolated from locations in the same vicinity formed one cluster.

Fig. 7. Dendrogram for T. harzianum 1 and T. harzianum 2 by the PAUP using bootstrap algorithm (Primer, R28).

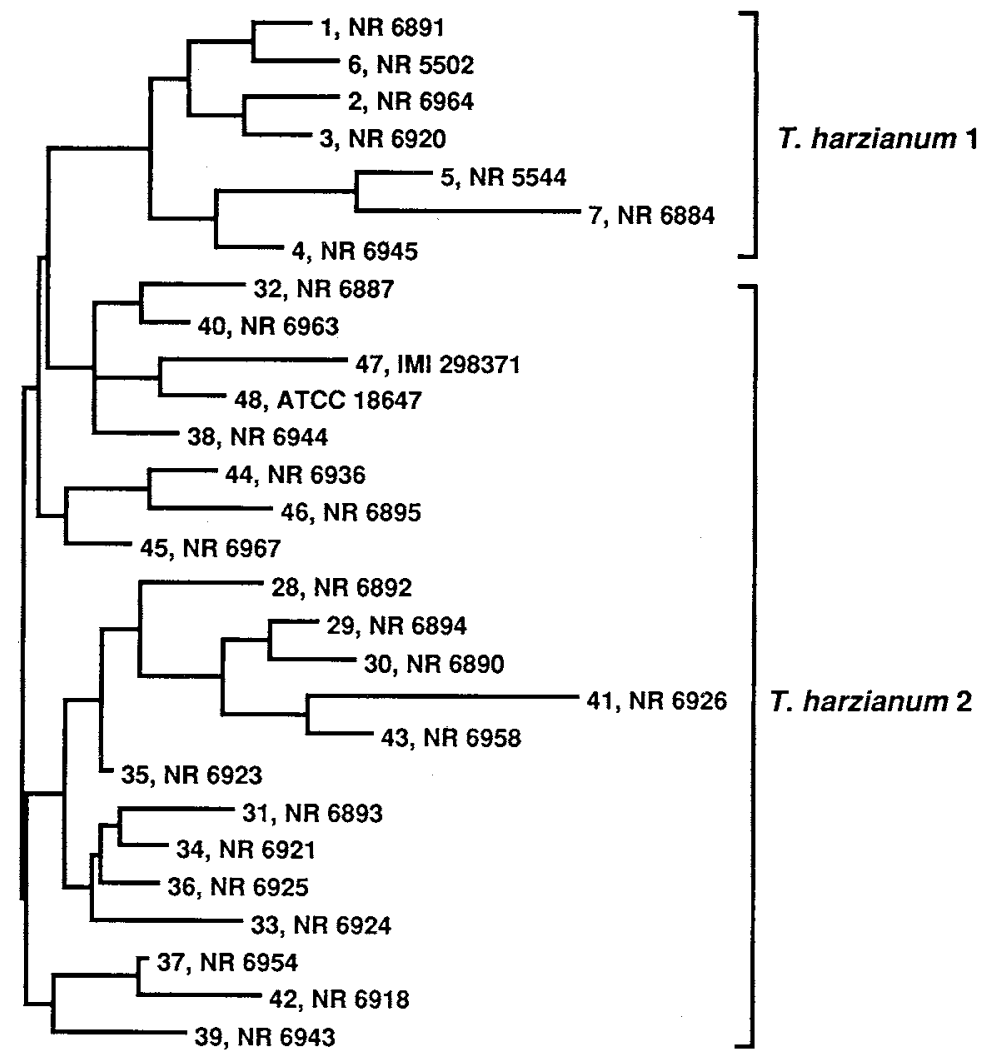

The number in front of the strain number indicates the number in the Table 1 and Fig. 6. The branch length represents the distance between strains. 
T. harzianum 2 NR 6890, NR 6892, and NR 6894 were combined in a cluster, and they were isolated from different substrates collected in Aichi Prefecture. T. harzianum 2 NR 6921 , NR 6924 and NR 6925 were also clustered together, isolated from samples collected in Gumma Prefecture. In fact, T. harzianum 2 NR 6921, NR 6924 and NR 6925 showed almost the same cultural and physiological characteristics. They produced yellow needle-like crystals and dark red brown pigments in agar. They did not grow at $37^{\circ} \mathrm{C}$ and very slowly at $34^{\circ} \mathrm{C}$, attaining a diameter of less than $15 \mathrm{~mm}$ after 4 days. While $T$. harzianum $2 \mathrm{NR}$ 6890, NR 6892, and NR 6894 did not produce yellow crystals but secreted red brown pigments in agar. They showed luxuriant growth at $34^{\circ} \mathrm{C}$, attaining a diameter of more than $50 \mathrm{~mm}$ after 4 days.

Similarly interesting results were obtained for $T$. viride: $T$. viride IMI 293250 , NR 5566, NR 6937, IMI 295977, IMI 304531 and FP 5566. They grew well at $34^{\circ} \mathrm{C}$, attaining a diameter of more than $50 \mathrm{~mm}$ after 4 days, whereas the other $T$. viride strains did not grow at $34^{\circ} \mathrm{C}$. The fast growers all produced isonitrile antibiotics; IMI 293250, NR 5566, NR 6937, IMI 295977, and IMI 304531 (parsimoniously connected according to Fig. 4) came from areas with warmer climates; India, Malaysia, and sourthern Japan such as Kumamoto and Okinawa; whereas, all the other $T$. viride strains were derived from temperate or northern countries. Among these temperate $T$. viride strains, three antibiotic producers, NR 5510, NR 5541 and CBS 433.34 were closely associated (Fig. 4). A similar result was also obtained for T. aureoviride (data not shown). The dendrogram constructed by the PAUP therefore demonstrated that RAPD results were consistent with morphological, physiological and ecological characteristics, and expressed differences between fungal strains.

\section{Conclusion}

Recently, techniques based on the PCR have been used to detect polymorphisms in various plants ${ }^{18)}$, animals $^{19)}$, and fungal species ${ }^{20)}$. Decameric primers are used to reproducibly amplify segments of genomic DNA from a wide variety of species ${ }^{21 \sim 23)}$. The arbitrarily-primed polymerase chain reaction (AP-PCR) and random amplified polymorphic DNA (RAPD) generate fingerprints of DNA products. Major advantages of both techniques over traditional RFLP are that rapid analysis is possible even with a small amount of partially purified DNA samples. RAPD has therefore been applied to taxonomic works and ecological studies to distinguish small genetic differences among strains, races, varieties, and species ${ }^{1,3,4)}$. The method is also useful for genetic mapping studies ${ }^{22}$.

RAPD analysis with PCR proved to be a powerful tool in the elimination of duplicate strains in the microbial screening program. The electrophoretic band patterns of 74 strains of Trichoderma correlated well with their morphological and cultural properties, metabolite production profiles and ecological data. Based on RAPD data, it was possible to select several strains by eliminating the other similar strains. Although the data is not shown, RAPD analysis with several other fungal genera gave similar results. Therefore, we conclude that the RAPD method is a simple, efficient and reliable method for the selection of fungal strains employed for screening.

In addition, we succeeded in the establishment of a standard method for RAPD to minimize the deviation of $\mathrm{Rf}$ values between gels less than 0.03 . Through image acquisition of electrophoretic band patterns by an image analyzer, the image data can be converted to $\mathrm{Rf}$ value data. The $\mathrm{Rf}$ value data is then converted to 0-1 data matrices. The matrix data is analyzed either by PC or main frame, so that the whole process can be automated.

\section{Acknowledgment}

We thank Dr. S. Tokumasu of the University of Tsukuba, Tsukuba, Japan for kindly allowing us to use his strains. Thanks are also due to Prof. J. BENNETT of Tulane University, New Orleans, U.S.A., for her discussion and generous suggestions.

\section{References}

1) Goodwin, P. H. \& S. L. ANNIS: Rapid identification of genetic variation and pathotype of Leptosphaeria maculans by random amplified polymorphic DNA assay. Appl. Environ. Microbiol. 57: 2482 2486, 1991

2) Williams, J. G. K.; A. R. Kubelik, K. J. LivaK, J. A. Rafalski \& S. V. Tingey: DNA polymorphisms amplified 
by arbitrary primer are useful as genetic markers. Nucleic Acids Res. 18: 6531 6535, 1990

3) Strongman, D. B.; Discrimination between Hirsutella longicolla var. longicolla and Hirsutella longicolla var. cornuta using random amplified polymorphic DNA fingerprinting. Mycologia 85: 65 70, 1993

4) Yoon, C.-S. \& D. A. Glawe: Association of random amplified polymorphic DNA markers with stromatal type in Hypoxylon truncatum sensu Miller. Mycologia 85: 369 380, 1993

5) MAYER, W.; R. MoRawetz, T. Börner \& C. KUBiceK: The use of DNA-fingerprint analysis in the classification of some species of the Trichoderma aggregate. Curr. Genet. 21: 27 30, 1992

6) CARder, J. C. \& D. J. BARBARA: Molecular variation and restriction fragment length polymorphisms (RFLPs) within and between six species of Verticillium. Mycol. Res. 95: 935 942, 1991

7) Rifal, M. A.: A revision of the genus Trichoderma. Mycological Papers No. 116, I 56. IMI, Surrey, United Kingdom, 1969

8) Veerkamp, J. \& W. Gams: Los hongos de Colombia-VIII. Some new species of soil fungi from Colombia. Caldasia $8: 709 \sim 717,1983$

9) BISSETt, J : A revision of the genus Trichoderma. I. Section Longibrachiatum sect. nov. Can. J. Bot. 62:924 931, 1984

10) BiSSETT, J.: A revision of the genus Trichoderma. II. Infrageneric classification. Can. J. Bot. 69: 2357 2372, 1991

11) Bissett, J.: A revision of the genus Trichoderma. III. Section Pachybasium. Can. J. Bot. 69: 2373 2417, 1991

12) BisSETt, J.: A revision of the genus Trichoderma. IV. Additional notes on section Longibrachiatum. Can. J. Bot. 69: $2418 \sim 2420,1991$

13) Okuda, T.; A. Fujwhara \& M. Fujiwara: Correlation between species of Trichoderma and production patterns of isonitrile antibiotics. Agric. Biol. Chem. 46: 1811 1822, 1982

14) Omori, Y.; M. Tsumura, T. Ichida \& K. Yamasato: Disrupting of fungus and actinomycetes cell with Cryo Clean Blaster (CCB). Japanese J. Freez. Dry. 36: 36 40, 1990

15) PANG, J.-P.; L.-C. ChEN, L.-F. O. ChEN \& S.-C. G. CHEN: DNA polymorphisms generated by arbitrarily primed PCR in rice. Biosci. Biotech. Biochem. 56: 1357 1358, 1992

16) Swofford, D. L.: PAUP, phylogenetic analysis using parsimony, version 3.0s. Illinois Natural History Survey, Champaign, Illinois, USA. 1991

17) Okuda, T.; M. Yanagisawa, S. Matsukuma \& A. Yamaguchi: Trichoderma forming green globose conidia. Abstracts of the Fouth International Mycological Congress, p 43, Regensburg, Germany, 1990

18) Klein-Lankhorst, R. M.; A. Vermunt, R. Weide, T. Liharska \& P. Zabel: Isolation of molecular markers for tomato (L. esculentum) using random amplified polymorphic DNA (RAPD). Theor. Appl. Genet. 83: 108 114, 1991

19) LehmanN, P. F.; D. Lin \& B. A. LASkeR: Genotypic identification and characterization of species and strains within the genus Candida by using random amplified polymorphic DNA. J. Clin. Microbial. 30: 3249 3254, 1992

20) Brousseau, R.; A. Saint-Onge, G. Préfontaine, L. Masson \& J. Cabana: Arbitrary primed polymerase chain reaction, a powerful method to identify Bacillus thuringiensis serovars and strains. J. Appl. Entomol. 59: 114 119, 1993

21) Wilde, J.; R. WAUGH \& W. Powell: Genetic fingerprinting of Theobroma clones using randomly amplified polymorphic DNA marker. Theor. Appl. Genet. 83: 871 877, 1992

22) Welsh, J.; C. Petersen \& M. McClelland: Polymorphisms generated by arbitrarily primed PCR in the mouse: application to strain identification and genetic mapping. Nucleic Acids Res. 19: 303 306, 1991

23) KHUSH, R. S.; E. BECKER \& M. WACH: DNA amplification polymorphisms of the cultivated mushroom Agaricus bisporus. Appl. Environ. Microbiol. 58: $2971 \sim 2977,1992$ 